\title{
Effect of depolymerized block skim rubber (BSR) on the physical properties of modified asphalt
}

\author{
Arief Ramadhan*, Adi Cifriadi, Henry Prastanto, Norma Arisanti Kinasih \\ Indonesian Rubber Research Institute, Jl. Salak No. 1, Bogor 16151, Indonesia \\ *Corresponding author. Tel: +62 815-9470-946 Fax: +62 2518324047 \\ E-mail: arifkaret@gmail.com
}

Submitted: 5 September 2018

Revised: 26 November 2018

Accepted: 26 November 2018

\begin{abstract}
The asphalt pavement susceptibility was influenced by traffic load and temperature. Therefore, modified asphalt has been done to improve the asphalt performance. Depolymerized block skim rubber (BSR) was used as asphalt modifier. BSR is a low quality crumb rubber, which made from skim (byproduct of creamed latex). This investigation aims to determine effect of depolymerization of BSR on the physical performance of modified asphalt. Initially, BSR was depolymerized by mechanical action (mastication) with different time of 8, 16, and 24 min. Then, the asphalt modifier, depolymerized BSR was added to asphalt with different ratio 3, 5, 7\%. The softening point and mixing time of asphalt were compared with modified asphalt. The performance of modified asphalt showed that asphalt modifiers increased the softening point and mixing time of asphalt. Maximum softening point reached $54.30^{\circ} \mathrm{C}$ by $7 \%$ BSR $\left(16\right.$ min. of mastication time). The modified asphalt had $25.70^{\circ} \mathrm{C}$ softening point higher than asphalt. It was conclude that depolymerized BSR can increase the performance of asphalt (softening point), although increase the mixing time of it. Moreover, it could give alternative to reduce cost of modified asphalt pavement making.
\end{abstract}

Keywords: Asphalt, block skim rubber, depolymerized, modified asphalt

\section{INTRODUCTION}

Asphalt pavement is a transportation facility on this modern era. Asphalt pavement has high frictional force, so the vehicle tires are not slip easily on wet or dry condition. However, asphalt pavement susceptibility was influenced by traffic load and temperature. Asphalt becomes brittle and has low-thermal cracked at low temperature (0$30^{\circ} \mathrm{C}$ ), whereas it flows and suffers from rutting at high temperature $\left(40-65^{\circ} \mathrm{C}\right)$ (Lewandowski, 1994). In tropical country, the highest temperature in summer time can attain $50^{\circ} \mathrm{C}$, which is higher than the softening point of asphalt $\left( \pm 48^{\circ} \mathrm{C}\right)$. This will reduce the service life of the pavement.

The potential solution for addressing today highways problems is mixing a polymer with the asphalt. The studies of polymer modified asphalt showed that the overall polymer mixture on asphalt had increase the performance of asphalt (Ali et al., 2013; Bakar et al., 2018; Ali et al., 2015; Huang et al., 2017). The majority polymer used for asphalt modifier were styrenebutadiene-styrene (SBS) (Chen et al., 2002; Martinez-Estrada et al., 2010; Kök \& Colak, 2011; Liu et al., 2014) and technically specified rubber (TSR) as crumb rubber or tire scrap form (Bai et al., 2016; Presti, 2013; Kök \& Colak, 2011; Prastanto, 2014).

Unfortunately, SBS, as synthetic rubber, and TSR, as natural rubber, are expensive materials compared with asphalt and the substantial improvement in performance could only achieve at an appraisal 25\% increase on material costs. Besides that, Indonesia has to import synthetic rubber, meanwhile Indonesian TSR (SIR 20) has been using as raw material of high quality products, such as tire, dock fender, bridge bearing, etc. One of the alternative solution is to utilize the second grade of natural rubber, which is block skim rubber (BSR).

BSR is a low quality of crumb rubber, which is made from skim. Skim natural rubber latex is the side product of centrifugal concentration of 
natural rubber latex containing high protein (George et al., 2009). Skim contains 4-8\% dry rubber content (DRC) (Blackely, 1966; George et al., 2009). Recently, the assumption of skim production per year in Indonesia reached 2,549 ton (Haris et al., 2010). The price of BSR per $\mathrm{kg}$ is around $40 \%$ of the SIR 20 price (7,743 IDR). It was cheaper than the price of SIR 20 per $\mathrm{kg}$ $(19,358$ IDR) and SBS per kg (182,108 IDR) on August 2018. Utilizing this waste material might turn out the solution of a waste disposal-problem and construction cost of roads.

$\mathrm{BSR}$, as natural rubber, has long polymer molecules chain that can lengthen the mixing time and needs higher energy to mix the asphalt. Depolymerization is polymer decipherment to shorten this polymer molecules chain. Depolymerization can be held by chemical (Prasoetsopha et al., 2011), thermal and mechanical (Nair et al., 1995) or mechanical action (Prastanto, 2014) on latex phase (Prasoetsopha et al., 2011; Nair et al., 1995) or rubber phase (Prastanto, 2014). In this research, depolymerization held by mechanical action using open mill at three different times of mastication.

Prastanto (2014) reported that mechanical depolymerization during 24 minutes decreased the molecular weight refer to decreasing of Mooney viscosity. Then, the depolymerized BSR will be used to modify asphalt making. This investigation aims to investigate the effect of depolymerized BSR on the physical performance of modified asphalt and to find optimum composition of depolymerized BSR as modifier in modified asphalt.

\section{MATERIALS AND METHODS \\ Material and Sample Preparation}

Asphalt (P60), obtained from Binamarga, was used as bitumen for mixture preparation. The skim rubber was supplied by PTPN 8. Afterward, the skim rubber was coagulated with sulfuric acid $2 \%$ and dried with oven. The properties of BSR was analyzed by standard test of Indonesian TSR (SIR 20). The properties of BSR are listed in Table 1. This properties was compared with quality standard of SIR 20.

BSR was depolymerized by mechanical action using open mill. The temperature of mastication was controlled under $60^{\circ} \mathrm{C}$. Depolymerization was held on two period gradually. Firstly, BSR (200 g) was masticated for 5 minutes then added with $0.2 \mathrm{phr}$ (per hundred rubber) peptizer. Furthermore, BSR was masticated again for three different time of mixing (8, 6, 24 min.). Then, $0.6 \mathrm{phr}$ hydroxylamine neutral sulfate (HNS) was added into BSR. The depolymerized BSR per each mixing time was utilized as asphalt modifier.

\section{Polymer Modified Asphalt Mixture}

A mixture of depolymerized BSR and asphalt was held on high temperature design. Asphalt (300 g) was added on stainless flask and heated by electrical stove at $160^{\circ} \mathrm{C}$. Sample temperature and heating rate was controlled by thermocouple. Mechanical rotor was started once the asphalt homogenous melt, rotor speed was adjusted to 20 rpm. Furthermore, depolymerized BSR was resized into small pieces sample prior to mix with liquid asphalt. The small pieces depolymerized BSR per each mixing time was added 3, 5, 7\% (\% w/t) into liquid asphalt separately. This mixture was mixed until homogenous. Then, the physical properties of polymer modified asphalt was analyzed.

\section{Testing Method \\ The properties of depolymerized BSR}

An analysis of depolymerized BSR properties was held to determine the effect of depolymerization on BSR properties, especially the polymer molecular chain length. The properties of depolymerized BSR was analyzed by standard test of SIR 20. The parameter properties analyzed including;

a) Initial plasticity $\left(\mathrm{P}_{0}\right)$ (SNI 06-1903-2000)

15-25 g samples was prepared previously. A sample was milled by open mill to homogenize the sample and flatten it became 1.6-1.8 mm thickness. Then, the sheet of sample was folded to increase the sample thickness became 3.2-3.6 $\mathrm{mm}$. A sample was cut down into three round shapes using Wallace punch. Furthermore, a round shape sample was put between two sheets of cigarette paper (TST) and tested it using Wallace plasticity meter. The measurement of initial plasticity was held twice to obtain accurate data.

b) Plasticity retention index (PRI) (SNI 06-19032000)

15-25 g samples was prepared previously. A sample was milled by open mill to homogenize the sample and flatten it become 1.6-1.8 mm thickness. Then, the sheet of sample was folded to increase the sample thickness become 3.2-3.6 $\mathrm{mm}$. A sample was cut down become three round 
shapes using Wallace punch. Furthermore, a round shape sample was put in oven at $140 \pm 0.2^{\circ} \mathrm{C}$ for 30 minutes. The sample plasticity after aging was measured using Wallace plasticity meter as $\mathrm{Pa}$. The measurement of plasticity retention index was held twice to obtain accurate data. PRI value was calculated with this formula:

$\mathrm{P}_{0}=$ Initial plasticity

$$
\text { PRI (\%) }=\frac{\mathrm{Pa}}{\mathrm{Po}} \mathrm{X} 100
$$

$\mathrm{Pa}=$ Plasticity after ageing in oven at $140 \pm 0.2^{\circ} \mathrm{C}$ for 30 minutes

\section{c) Mooney viscosity (ASTM D-1076-97)}

Initially, the temperature of Mooney viscometer was set $100^{\circ} \mathrm{C}$ for 1 minute. After that, a sample ( $\pm 25 \mathrm{~g})$ was put on the up and down the rotor in that machine and the rotor was rotated for $4 \mathrm{~min}$. The energy required to rotate the rotor was read on the scale. The unit of Mooney viscosity value is $\mathrm{M}\left(1^{\prime}+4^{\prime}\right) \mathrm{L} 100^{\circ} \mathrm{C}$.

\section{The physical properties of polymer modified asphalt}

The properties of the polymer modified asphalt was analyzed to determine the effect of addition asphalt modifier on asphalt, compared it to asphalt. The physical properties of modified asphalt was analyzed including;

a) The mixing time of modified asphalt

The mixing time of modified asphalt is the time needed to blend the asphalt and polymer. The calculation of mixing time started when asphalt melted until all of the polymer mixture homogenous with asphalt. The calculation time measured by stop watch.

b) Softening point

Softening points were used to determine the temperature at which a phase change occurs in the binder. Initially, two brass rings was layered with glycerin, then chilled at room temperature for 30 min. A sample was melted to become liquid phase, then the sample was poured into brass ring. That sample was chilled at room temperature for $1 \mathrm{~h}$. After that, the brass rings was fitted with ball centering guide (put into the center of brass rings) inside ring holder. Furthermore, the tools measurement was put into container of aqua. In other side, the thermometer was put into the hole of tools measurement (Figure 1). The container was heated so that its temperature rise reached $5^{\circ} \mathrm{C} / \mathrm{min}$. The softening point was taken as the temperature at which the sample became soft enough to allow the ball, enveloped in the sample

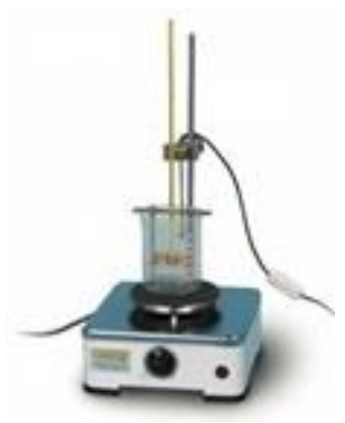

Figure 1. Softening point instrument.

material, to fall a distance of $25.4 \mathrm{~mm}$. This was recorded as the softening temperature.

\section{RESULTS AND DISCUSSION The Properties of Depolymerized BSR}

The properties of BSR (Table 1) shows that BSR has quietly met a SIR standard, which are ash content and dirt content properties. That result describes that BSR has low ash and dirt content. The skim latex has low dirt content and it potentially becomes high quality rubber if the protein content can be increased and problems arising from coagulation are solved (Alex \& Nah, 2006). Nevertheless, BSR has high nitrogen and volatile materials content (such as water vapor or serum) and has shorter polymer molecular chain and lower stability on high temperature than SIR 20.

Both $\mathrm{P}_{0}$ and Mooney viscosity are decreasing with the increasing of mastication time (Figure 1). Depolymerization held by milling process using open mill. Masticating rubber for longer time, will make rubber becomes more plastic than the unmasticated. An elastic rubber has low molecular chain length and molecular weight. The addition of peptizer on mastication process has gave polymer molecule weight decrease effect too on depolymerized BSR.

The depolymerization process comparison of BSR and SIR 20 (Figure 2) shows insignificantly different. The raw material of polymer does not influence the succession of depolymerized process. The depolymerization at 24 minutes of mastication time has the highest percentage of Mooney viscosity degradation on both of that rubber. The BSR depolymerized can achieve 93.54\% degradation of Mooney viscosity, whereas SIR 20 can achieve $86.46 \%$ degradation of Mooney viscosity. It means that the depolymerization process of BSR is more successful than SIR 20, even though SIR 20 has better properties than BSR. 


\section{The Physical Properties of Polymer Modified Asphalt}

Asphalt is a heterogeneous material consists of immiscible phase of asphaltenes and maltenes. Asphaltenes are polyatomic hydrocarbons of relatively high molecular weight. Maltenes are a mixture of resins, waxes, aliphatic and aromatic compounds (Browarzik et al., 1999; Murgich et al., 1996). The addition of polymer in asphalt could raise the properties of asphalt (Kanitpong \& Bahia, 2005; Chen et al., 2002; Hussein et al., 2006; Tuntiworawit et al., 2005). The morphology of asphalt and polymer blend was studied using SEM showed that both of them was blended homogenously (Chen et al., 2002; Xiang et al., 2009). This result concluded that polymer had compatible with asphalt matrix, which could increase the asphalt performance.
The mixing and applying technique of asphalt-rubber to roads mainly use two ways, the dry and wet process (Huang et al., 2007). Crumb rubber is used as a part of the aggregate in the hot mixture to replace some of the solid fraction in a dry process (Azizian et al., 2003). While others, crumb rubber is added to the asphalt cement mixture in a wet process. In this research, the mixture of asphalt and depolymerized BSR was prepared by wet process. The wet process can rectify the rutting resistance, resilience modulus, and fatigue cracking resistance of asphalt mixtures (Mashaan et al., 2014) because wet process stimulates rubber particles absorb the aromatic fractions of asphalt as much as possible, and increases the viscosity of the asphalt (Ibrahim et al., 2013).

Table 1. BSR properties.

\begin{tabular}{|c|c|c|}
\hline Properties $(\%)$ & BSR & SIR 20 \\
\hline Volatile matter content & 2.78 & Max. 0.8 \\
\hline Ash content & 0.62 & Max. 1.0 \\
\hline Dirt content & 0.013 & Max. 0.2 \\
\hline Initial plasticity $\left(\mathrm{P}_{0}\right)$ & 26.00 & Min. 30 \\
\hline Plasticity retention index (PRI) & 15.40 & Min. 50 \\
\hline Nitrogen content & 2.23 & Max. 0.6 \\
\hline
\end{tabular}

Table 2. The properties of depolymerized BSR.

\begin{tabular}{lcccc}
\hline \multirow{2}{*}{ Properties } & \multirow{2}{*}{ BSR } & Depolymerized BSR on different mastication time \\
\cline { 3 - 5 } & & $8 \mathrm{~min}$ & $16 \mathrm{~min}$ & $24 \mathrm{~min}$ \\
\hline Initial plasticity $\left(\mathrm{P}_{0}\right)$ & 26.00 & 11 & 10 & 7 \\
Plasticity retention index $(\%)$ & 15.40 & 18.20 & 30.00 & 28.60 \\
Mooney viscosity & 49.5 & 9.3 & 9.0 & 3.2 \\
{$\left[\mathrm{M}\left(1^{\prime}+4^{\prime}\right) \mathrm{L} 100^{\circ} \mathrm{C}\right]$} & & & & \\
\hline
\end{tabular}

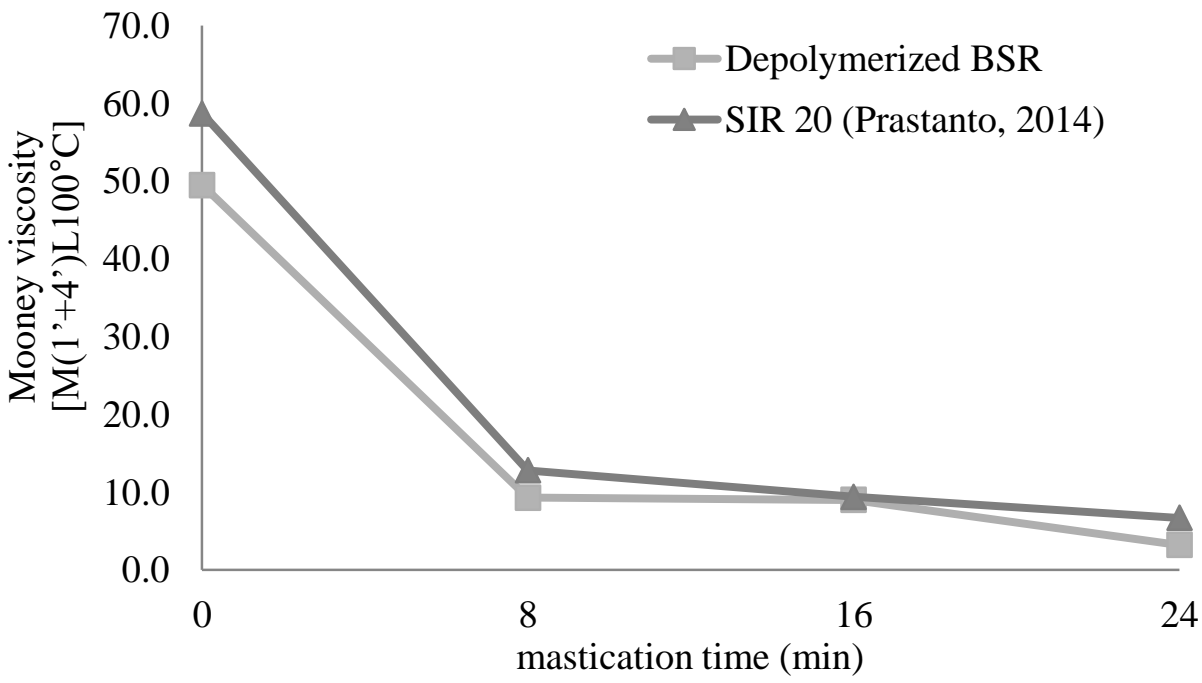

Figure 2. The Mooney viscosity of depolymerized BSR. 
The mixing time describes the time needed to homogenize the asphalt blending with asphalt modifier. The mixing time of asphalt (without modifier) is $330 \mathrm{~min}$. whereas the addition of depolymerized BSR increase the mixing time of asphalt become 313-416 min. The addition of higher concentration of depolymerized BSR was also increase the mixing time of asphalt as shown in Figure 3. The increasing of mixing time was caused by the addition of asphalt modifier, which is a solid form. So that, it needs extra time to melt and blend it with asphalt.

Addition of $3 \%$ SIR 20 (without depolymerization) on asphalt needed $660 \mathrm{~min}$. of mixing time (Prastanto, 2014). As compare to the addition of 3\% depolymerized BSR needed 313$331 \mathrm{~min}$. of mixing time. This result shows that depolymerization can reduce the mixing time of modified asphalt. The depolymerization decrease the height and weight of polymer molecules, was accordance to low $\mathrm{P}_{0}$ and Mooney viscosity. The low $\mathrm{P}_{0}$ was fasten the mixing time of asphalt (Cifriadi et al., 2012). The fastest mixing time is 313 minutes, which produced by 16 minutes mastication time and $3 \%$ addition of depolymerized BSR treatment. This value has decrease closely $50 \%$ of the mixing time of asphalt, which prepared by undepolymerized rubber (SIR 20).

Successful of asphalt modifier is not only showed from decreasing of mixing time but also the increasing of modified asphalt softening point. The softening point of asphalt is $49.30^{\circ} \mathrm{C}$, while the softening point of modified asphalt are 49.75$54.3^{\circ} \mathrm{C}$ (Figure $3 \&$ Figure 4). This result shows that depolymerized BSR can increase the softening point of asphalt, which linearly with Bakar's et al. (2018) result. Bakar et al. (2018) reported that the addition of waste NR latex into bitumen increased the resistance of bitumen to temperature changes which refers to the increasing value of softening points. Depolymerized BSR was become matrix binder in amorphous texture of asphalt matrix. Cohesive property and plasticity of crumb rubber was delivered to crumb rubber modified asphalt (Huang et al., 2001). Those reasons related to the increasing of softening point.

Table 3. Softening point of modified asphalt.

\begin{tabular}{|c|c|c|}
\hline Polymer & Treatment & Softening point $\left({ }^{\circ} \mathrm{C}\right)$ \\
\hline BSR & $\begin{array}{l}\text { Depolymerized on } 16 \text { minutes of mastication time. } 3 \% \\
\text { depolymerized BSR was added using wet process }\end{array}$ & 54.3 \\
\hline SIR 20 & $\begin{array}{l}\text { Depolymerized on } 8 \text { minutes of mastication time. } 7 \% \\
\text { depolymerized SIR } 20 \text { was added using wet process }\end{array}$ & $56.5^{1)}$ \\
\hline SBS & $6 \%$ SBS was added using wet process & $68.6^{2)}$ \\
\hline CR (scrap tire) & $\begin{array}{l}\text { Crumb rubber modified asphalt was prepare by } \\
\text { traditional wet process }\end{array}$ & $49.8^{3)}$ \\
\hline $\begin{array}{l}\text { Concentrated } \\
\text { latex }\end{array}$ & $\begin{array}{l}13 \% \text { by total weight of Concentrated latex }(60 \% \text { DRC) } \\
\text { mix into liquid asphalt }\end{array}$ & $60^{4)}$ \\
\hline 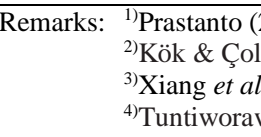 & $\begin{array}{l}\text { 11) } \\
\text { 9) } \\
\text { al. (2005) }\end{array}$ & \\
\hline
\end{tabular}
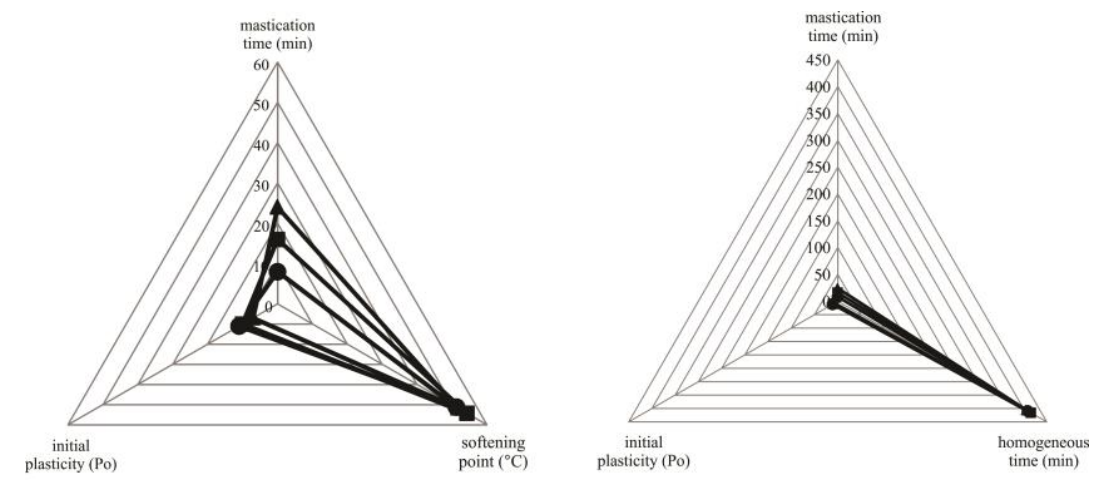

Figure 3. Physical properties of the addition of $\overrightarrow{8^{8} \text { mastication time }} \overrightarrow{\mathbf{H}^{-1} \text { mastication time }}$ depolymerized BSR. 

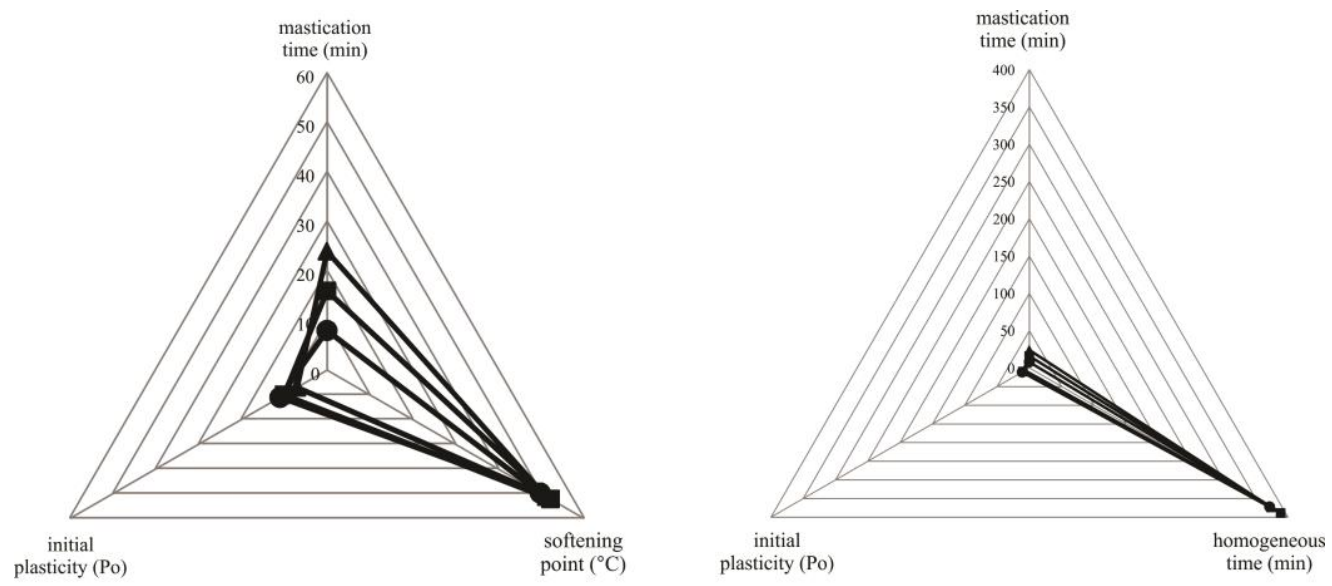

$\rightarrow 8^{\prime}$ mastication time

(a)
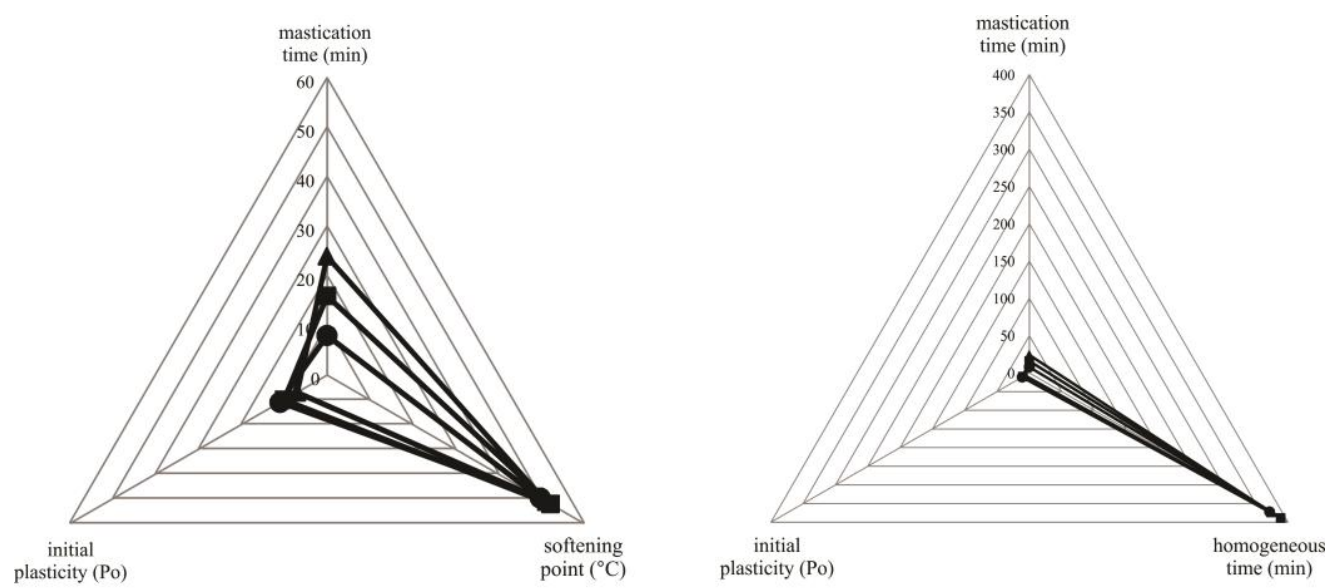

(b)

Figure 4. Physical properties of the addition of 5\% depolymerized BSR (a), depolymerized 7\% BSR (b).

The highest softening point is reached by the addition of $7 \%$ depolymerized BSR, which is masticated for 16 minutes. This value meets the minimum softening point of polymer asphalt standard (SNI 6749:2008), which is $54^{\circ} \mathrm{C}$. Compared with other research that used other polymer as asphalt binder (Table 3 ), the softening point of depolymerized BSR is higher than scrap tire (crumb rubber) and lower than depolymerized SIR 20, concentrated latex and SBS. In general, this research describes that addition of depolymerized BSR concentration decrease the softening point as shown in Figure 2. This test result is agree well with the research test of Chen et al. (2002). The addition of SBS concentration until $9 \%$ was made a mixture of asphalt and SBS dominant. A large degree of incompatibility is shown in the large polymer domain morphologically, which causes a decrease in engineering properties due to differences in molecular weight, polarity, and structure, chemical inequalities between bitumen and SBS. Morphology is the result of the reciprocal interaction of SBS and asphalt and, consequently, is influenced by the composition of the asphalt and the nature of the polymer and content.

\section{CONCLUSION}

BSR has quietly met a standard of SIR, which appropriate of the ash and dirt content. Depolymerization is done successfully, decreases 73\% $\mathrm{P}_{0}$ become 7 , decreases $93.5 \%$ Mooney 
viscosity become $3.2\left[\mathrm{M}\left(1^{\prime}+4^{\prime}\right) \mathrm{L} 100^{\circ} \mathrm{C}\right]$, and increases $85 \%$ PRI become 28.6. The decreasing of $\mathrm{P}_{0}$ fastens the mixing time of depolymerized BSR and asphalt. However, addition of depolymerized BSR concentration decreases the softening point. The optimum composition of asphalt modifier is $3 \%$ addition of depolymerized BSR (16 minutes mastication time). The optimum composition reduces 347 minutes of mixing time and increases $2.2^{\circ} \mathrm{C}$ of softening point.

\section{ACKNOWLEDGEMENT}

Authors acknowledge the Indonesian Rubber Research Institute for the in-house research grant.

\section{REFERENCES}

Alex, R., \& Nah, C. (2006). Preparation and characterization of organoclay-rubber nanocomposites via a new route with skim natural rubber latex. Journal of Applied Polymer Science, 102(4), 3277-3285. https://doi.org/10.1002/app.24738

Ali, S. A., Yusof, I., Hermadi, M., Alfergani, M. B. S., \& Sinusi, A. A. (2013). Pavement performance with carbon black and natural rubber (latex). International Journal of Engineering and Advanced Technology, 2(3), 2249-8958.

Ali, S. I. A., Ismail, A., Yusoff, N. I. M., Karim, M. R., Al-Mansob, R. A., \& Alhamali, D. I. (2015). Physical and rheological properties of acrylatestyrene-acrylonitrile modified asphalt cement. Construction and Building Material, 93, 326-334. https://doi.org/10.1016/j.conbuildmat.2015.05.01 6

Azizian, M. F., Nelson, P. O., Thayumanavan, P., \& Williamson, K. J. (2003). Environmental impact of highway construction and repair materials on surface and ground waters case study: Crumb rubber asphalt concrete. Waste Management, 23(8), 719-728. https://doi.org/10.1016/S0956053X(03)00024-2

Bai, F., Yang, X., \& Zeng, G. (2016). A stochastic viscoelastic-viscoplastic constitutive model and its application to crumb rubber modified asphalt mixtures. Materials \& Design, 89, 802-809. https://doi.org/10.1016/j.matdes.2015.10.040

Bakar, S. K. A., Abdulah, M. E., Kamal, M. M., Rahman, R. A., Hadithon, K. A., Buhari, R., \& Tajudin, S. A. A. (2018). Evaluating the rheological properties of waste natural rubber latex modified binder. E3S Web of Conferences, 34(1), https://doi.org/10.1051/e3sconf/20183401037

Blackely, D. C. (1966). High polymer latices: Their science and technology. Volume I: Fundamental principles. London, UK: Maclaren.

Browarzik, D., Laux, H., \& Rahimian, I. (1999). Asphaltene flocculation in crude oil systems.
Fluid Phase Equilibria, 154(2), 285-300. https://doi.org/10.1016/S0378-3812(98)00434-8

Chen, J. S., Liao, M. C., \& Tsai, H. H. (2002). Evaluation and optimization of the engineering properties of polymer-modified asphalt. Practical Failure Analysis, 2(3), 75-83. https://doi.org/10.1007/BF02719194

Cifriadi, A., Ramadhan, R., \& Prastanto, H. (2012). Accelerate time mixture of asphalt and rubber using black liquor for manufacturing of modified asphalt. Proceedings of National Rubber Conference, 319-399.

George, K. M., Alex, R., Joseph, S., \& Thomas, K. T. (2009). Characterization of enzyme-deproteinized skim rubber. Journal of Applied Polymer Science, 114(5), 3319-3324 https://doi.org/10.1002/app.30642

Haris, U., Prastanto, H., Alfa, A. A., \& Maspanger, D. R. (2010). The economic potential of skim latex processing on latex concentrate industry: Indonesian case. Proceedings of IRRDB International Rubber Conference, 687-693.

Huang, P., Weiming, L., \& Fuqing, Z. (2001). Research on performance and technology of the rubber powder modified asphalt mixture. China Journal of Highway Transport, 14, 4-7.

Huang, Y., Bird, R. N., \& Heidrich, O. (2007). A review of the use of recycled solid waste materials in asphalt pavements. Resources, Conservation and Recycling, 52(1), 58-73. https://doi.org/10.1016/j.resconrec.2007.02.002

Huang, W., Lin, P., Tang, N., Hu, J., \& Xiao, F. (2017). Effect of crumb rubber degradation on components distribution and rheological properties of terminal blend rubberized asphalt binder. Construction and Building Materials, 151, 897-906. https://doi.org/10.1016/j.conbuildmat.2017.03.22 $\underline{9}$

Hussein, I. A., Wahab, H. I. A., \& Iqbal, M. H. (2006). Influence of polymer type and structure on polymer modified asphalt concrete mix. The Canadian Journal of Chemical Engineering, 84(4), 480-487. https://doi.org/10.1002/cjce.5450840409

Ibrahim, M. R., Katman, H. Y., Karim, M. R., Koting, S., \& Mashaan, N. S. (2013). A review on the effect of crumb rubber addition to the rheology of crumb rubber modified bitumen. Advances in Materials Science and Engineering, 1-8. https://doi.org/10.1155/2013/415246

Kanitpong, K., \& Bahia, H. (2005). Relating adhesion and cohesion of asphalts to the effect of moisture on laboratory performance of asphalt mixtures. Transportation Research Record: Journal of the Transportation Research Board, 1901(1), 33-43. https://doi.org/10.1177/0361198105190100105

Kök, B. V., \& Çolak, H. (2011). Laboratory comparison of the crumb-rubber and SBS 
modified bitumen and hot mix asphalt. Construction and Building Materials, 25(8), 3204-3212.

https://doi.org/10.1016/j.conbuildmat.2011.03.00 $\underline{5}$

Lewandowski, L. H. (1994). Polymer modification of paving asphalt binders. Rubber Chemistry and Technology, 67(3), 447-480. https://doi.org/10.5254/1.3538685

Liu, G., Nielsen, E., Komacka, J., Greet, L., \& van de Ven, M. (2014). Rheological and chemical evaluation on the ageing properties of SBS polymer modified bitumen: From the laboratory to the field. Construction and Building Materials, 51 ,

244-248. https://doi.org/10.1016/j.conbuildmat.2013.10.04 $\underline{3}$

Mashaan, N. S., Ali, A. H., Karim, M. R., \& Abdelaziz, M. (2014). A review on using crumb rubber in reinforcement of asphalt pavement. The Scientific World Journal, 1-21. https://doi.org/10.1155/2014/214612

Martinez-Estrada, A., Chavez-Castellanos, A. E., Herrera-Alonso, M., \& Herrera-Najera, R. (2010). Comparative study of the effect of sulfur on the morphology and rheological properties of SB- and SBS-modified asphalt. Journal of Applied Polymer Science, 115(6), 3409-3422. https://doi.org/10.1002/app.31407

Murgich, J., Rodriguez, J., \& Aray, Y. (1996). Molecular recognition and molecular mechanics of micelles of some models asphaltenes and resins.
Energy $\quad$ Fuels, $\quad$ 10(1), 68-76. https://doi.org/10.1021/ef950112p

Nair, N. R., Claramma, N. M., Mathew, N. M., Thomas, S., \& Rao, S. S. (1995). Flow properties of thermally depolymerized liquid natural rubber. Journal of Applied Polymer Science, 55(5), 723731. https://doi.org/10.1002/app.1995.070550508

Presti, D. L. (2013). Recycled tyre rubber modified bitumens for road asphalt mixtures: A literature review. Construction and Building Materials, 49, 863-881.

https://doi.org/10.1016/j.conbuildmat.2013.09.00 7

Prastanto, H. (2014). Depolimerisasi karet alam secara mekanis untuk bahan aditif aspal. Jurnal Penelitian Karet, 32(1), 81-87.

Prasoetsopha, N., Chumsamrong, P., \& Suppakarn, N. (2011). Effects of type and concentration of initiator on grafting of acrylic monomer onto depolymerized natural rubber. Advanced Materials Research, 264-265, 565-570. https://doi.org/10.4028/www.scientific.net/AMR. $\underline{264-265.565}$

Tuntiworawit, N., Lavansiri, D., \& Phromsorn, C. (2005). The modification of asphalt with natural rubber latex. Proceedings of the Eastern Asia Society for Transportation Studies, 5, 679-694.

Xiang, L., Cheng, J., \& Que, G. (2009). Microstructure and performance of crumb rubber modified asphalt. Construction and Building Materials, 23(12), 3586-3590. https://doi.org/10.1016/j.conbuildmat.2009.06.03 $\underline{8}$ 